\title{
Women in the Ancient Roman Republic: Feminine Roles During the Reign of Julius Caesar
}

\author{
Yuting $\mathrm{Xie}^{1 \mathrm{a} *}$
}

\author{
${ }^{1}$ Roland Park Country School, Baltimore, MD 21210, USA \\ ${ }^{a}$ XieY@rpcs.org
}

\begin{abstract}
Using methods including analyzing primary historical documents, images, and secondary sources, this paper explores the multiple factors that resulted in the involvement of Ancient Roman women in the political field: political marriages and non-negligible roles in a family. Due to the benefits of political marriages, the two families would become allies and help each other make more extraordinary achievements in political and economic realms. Moreover, women's roles in the domestic sphere were crucial as well. As wives, mothers, and daughters, they had a moral obligation to raise children, take care of the household, and remained virtuous to keep up the families' reputations. Though many women were unknown, they still left a significant mark on the course of events. Despite their inferior status relative to men, women who lived in Ancient Rome closely connected to the dynamics of political power through marriages and their roles in the domestic sphere; using gender studies lens, this paper will explore three generations of women in Julius Caesar's family: Aurelia, Cornelia, and Julia to discuss how they influenced politics during the reign of Julius Caesar. To begin, this paper provides an overview of essential historical context, including the rise of Julius Caesar, Women's Status in Ancient Rome, and Marriages and Political Influences. Next, this paper argues that women could indirectly impact politics because of marriages and women's memorable roles in society and the home. This paper chose three exemplifications in Julius Caesar's family to discuss their significant influences on Julius Caesar to elaborate on this idea.
\end{abstract}

Keywords: gender studies, women in Ancient Rome, Julius Caesar, Roman Republics, politics in Ancient Rome

\section{INTRODUCTION}

"Woman is a violent and uncontrolled animal, and it is useless to let go the reins and then expect her not to kick over the traces. You must keep her on a tight rein [...] Women want total freedom or rather - to call things by their names - total licence. If you allow them to achieve complete equality with men, do you think they will be easier to live with? Not at all. Once they have achieved equality, they will be your masters ..." --- Cato the Elder [1]

\subsection{The Rape of Lucretia}

In 509 BCE, as shown in Figure 1, a noblewoman called Lucretia underwent a terrible sexual assault by Sextus, the eldest son of Tarquinius. After being raped, Lucretia committed suicide. The account of her story varied in different books as it appeared in Ab Urbe
Condita Libri by Livy and Roman Antiquities Book I by Dionysius of Halicarnassus. Even though Lucretia's story remained semi-mystical, the attack towards Lucretia symbolically marked the end of the regime of the Roman kingdom and forever influenced Roman society.

People got to understand Lucretia from the description of Livy, an Ancient Rome historian; in his book, he describes Lucretia as a model woman who committed suicide and decided not to bring dishonor to her family. Losing virginity or purity would be a disaster for both the victim and her family. As he recalls:

"How can anything go well for a woman who has lost her honor? There are the marks of another man in your bed, Continue. My body is greatly soiled, though my heart is still pure, as my death will prove. It is your responsibility to see that he gets what he deserves," she said, "I will absolve myself of blame, and I will not free myself from punishment. No woman shall use Lucretia as her example in dishonor." Then she took up a knife which 
she had hidden beneath her robe, and plunged it into her heart, collapsing from her wound. [2]

As Livy mentioned, it would be a tragedy if the "marks of some other man" and "a woman whom have forfeited her honor" remained forever. If a woman had lost her honor, it would be a disaster for the woman and her family. Based on Roman traditional culture, virtue was crucial for portraying people's characteristics, especially for women. The myth of Lucretia fully demonstrated Roman virtues and imagination that Roman people, specifically men, depicted for an ideal woman. For instance, an ideal situation for a "dishonored" woman was that she killed herself to prove her innocence and protect her family from being humiliated, as Lucretia did. Livy depicts her as a selfless woman who emphasized honor and reputation and established a model for all women to understand how crucial it was to be "pure" even if their bodies were "soiled". Moreover, people saw her as a brave and determined person, which elated her moral qualities; her bravery influenced Roman people for decades and encouraged them to fight for their emancipation after suffering through the suffocating tyranny.

For centuries, people regarded Lucretia as an oppressed woman. However, she had specific power as a human being. Her story inspired the historical revolution against the last Roman monarchy when portraying her as a symbol of courageous resistance to the oppression of a Roman dictator. [3] At the conclusion of the story, Lucretia committed suicide due to the "disgrace" from the rape, but the impacts of her death would be profound. Lucretia did not comprise; instead, she decided to revolt against the oppressors and revealed her resentment. In other words, her steadfastness incited people to rebel; indeed, Livy discussed in his book: "Brutus, leaving them in their grief, withdrew the knife from Lucretia's wound, and holding it all covered with blood up in the aid, cried ... by this blood, which was so pure before the crime of the prince, I promise before you, $\mathrm{O}$ gods, to chase the King Lucius Tarquinius Superbus, with his criminal wife and all their descendants, by fire, iron, and all the methods I have at my disposal, and never to tolerate Kings in Rome evermore, whether of that family of any other." [2]This paragraph illustrated Lucretia's anger and brought the story to a climax. Using seditious language, the author successively described how Lucretia's death had affected Roman people not to tolerate the "evil" King of Rome. In terms of the founding of republics, Melissa Mathes, who polished The rape of Lucretia and the Founding of Republics, explained that feminine power was a critical factor in transforming society. The stories that explained and constituted the foundation of republics are also often related to women, specifically the interaction of feminine trauma and the arousal of female power. [4] Since women's struggles have been longstanding issues, people began to recognize the violence towards women who were relatively less potent in an ancient patriarchal society. People connected the regime's tyranny to the sexual assaults happening to Lucretia; in this way, they could sense Lucretia's pain from their suffocating life experiences under the monarchy. Because they longed for freedom and a hopeful future, so they started to resist.

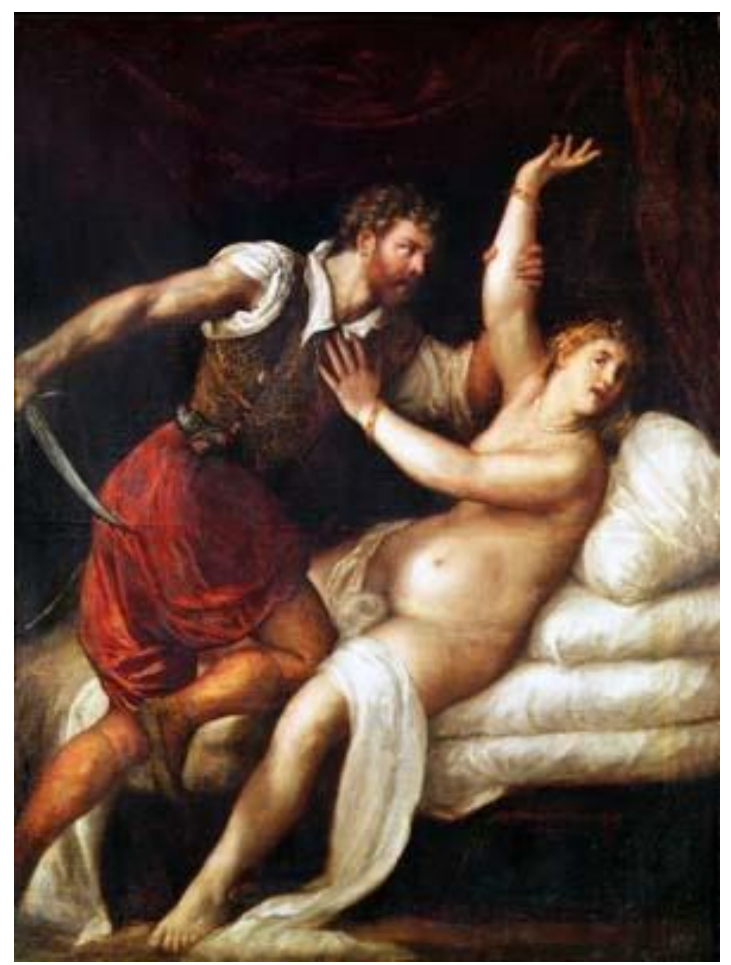

Figure 1. Sextus threatening Lucretia [5]

Inspired by Lucretia's compelling story, this paper explores the history, gender roles, and significance of Ancient Roman women in politics. To begin, this paper provides an overview of essential historical context, including the rise of Julius Caesar, women's status in Ancient Rome, and marriages and political influences. Next, this paper argues that women indirectly impacted politics due to marriages and women's notable roles in society and the home. To elaborate this idea, this paper selected three exemplifications in Julius Caesar's family: Aurelia, Cornelia, and Julia, to further discuss their significant influences on Julius Caesar.

\section{HISTORICAL CONTEXT: BACKGROUND OF JULIUS CAESAR, WOMEN IN THE ANCIENT ROMAN REPUBLIC, AND MARRIAGES}

\subsection{The Rise of Julius Caesar}

Julius Caesar was undoubtedly one of the most influential leaders of the ancient world. His story was still captivating and intriguing to generations of people. One of the most significant achievements he had accomplished throughout his life was overturning the Roman Republic; 
he shifted the reign of the Roman Republic to the Roman Empire.

The political center of the Roman Republic was the Senate. The people of Rome realized that a lifelong authoritarian king would inevitably lead to tyranny, and vigilance against dictators became the creed of the Roman people of the Republic. The Senate decided to elect consuls. A consul held the highest political office in the Roman Republic, but their terms were only one year each time. In addition, the social class system was rigid: two elites, patricians, and equestrians dominated Roman politics and economics while other ordinary people had no place or significant positions in society. With the development of the economy, the economic gap between the plebeians and the nobilities widened, and the political status of the plebeians also decreased relatively. The aristocracy entirely controlled the Senate, and the conflicts between the plebeians and the nobles became more serious. As a result of the conflicts, the nobles compromised and elected tribunes once a year. The primary duty of the tribunes was to speak for the plebeians, appeal and protest to the consuls and the Senate, and oppose any official's abuse of power. The Senate gave the tribunes an extraordinary power. If any consul tried to oppress a plebian, they had the power to declare his actions invalid or to prevent him from doing so. Also, anyone who prevented them from performing the tribunes' duties or who posed threats to them was declared a gangster, and the tribune could kill him. Even though the tribunes could not decide anything, but they could deny anything. The tribunes' existence prevented the conflict between the plebeians and the nobles and maintained the Roman social structure stability.

Moreover, since the Senate controlled Rome for a long time, many nobles were frustrated with the conservatism and control of the Senate. Thus, they planned to overthrow the system and created a revolutionary new government. Caesar formed an informal alliance with other influential leaders to provide stability and secure their political aims like other leading figures in Rome. [6] In this case, Caesar established the First Triumvirate with Pompey and Crassus. Professor Thomas N. Mitchell's article clearly illustrated the efficiency of the coalition formed by Caesar, Pompey, and Crassus. The aristocracy's shortsightedness and spiteful envy led to the formation of this coalition, which ruled Rome in 59 and signalled the end of republicanism. In seeking to humiliate independent and preeminent members, the aristocracy drove them together and ended the Republic. [7] Most importantly, this allyship allowed Caesar to become Consul in 59 and initiate a series of reforms to improve Roman's life. The widespread reputation was a key to Caesar's later success in his military career.

In $52 \mathrm{BC}$, Caesar gained a complete victory in Gaul that resulted in an expansion of the Roman Republic without the sanction of the Senate. In the aftermath of the conquest of Gaul, he sent his troops across the Rubicon and occupied Rome. At this point, Caesar became the most powerful leader, but he had many enemies too. One good example was Pompey. He allied with the conservative Senators to fight against Caesar. Under this circumstance, Caesar understood that he had to defeat Pompey even though it was an arduous task. He smashed Pompey's army at Pharsalus and had himself declared Dictator when he got back in Rome. By now, he had become the sole ruler of Rome, which allowed him to have extraordinary powers.

\subsection{Women's Status in Ancient Rome}

Women were expected to be chaste and modest. The dress of a Roman matron was designed to entirely cover her; statues often represent women making a special gesture to indicate their modesty. It was critical to be faithful to one's marriage. Furthermore, women were frowned upon for being avaricious, ambitious, showy, or self-promoting because these characteristics were masculine, and women should not go beyond men. [8] In the male-dominated Roman Republic, men wrote all history, documents, and laws. In this case, men put themselves in a high position, and women were excluded from power, so women could not have equal political or social status.

Women in ancient Rome suffered from inequality with men; people regarded women as inferior to men in such a macho and patriarchal society. For example, even though freeborn women were citizens, they could not vote or hold any political power in offices. Throughout their life, ancient Roman women's roles changed from daughters to wives and mothers. Despite their importance in families for raising kids and managing households, they were still under the control of men such as fathers and husbands.

In the early days of the Roman Republic, women were seen as the weak and the ignorant representatives. In the Twelve Tables (Lex XII Tabularum), one of the first sets of laws created by the government to regulate citizens' behaviors in the Roman Republic, women needed lifelong guardianship. “... Women, even though they are of full age, because of their levity of mind shall be under guardianship... except vestal virgins, who... shall be free from guardianship...." [9] On top of that, most guardians of women were men. In this case, women lost much freedom and were restricted by such inhumane rules created by men. Because in Early Rome, the head of the households were fathers (also known as pater familias). They controlled their dependents and created morals or norms for women to obey, and women were also the dependents in families. This norm suggested that women had to obey the restrictive rules established throughout their whole life by men, which explained why men were always dominating in both offices and families while 
women had to keep up their fidelity to reinforce morality that the society labelled on them.

\subsection{Marriages and Political Influences}

In the traditional Ancient Rome society, marriage was quite different from that of modern society. It was more like a negotiation, agreement, and alliance between two families. Therefore, in some ways, Ancient Roman people did not promote "free love" relationships because mostly, the parents would arrange marriages for their children; they expected children to accept the decisions even if they preferred not to.

In general, men would usually marry in their twenties while women married much earlier, such as in their early teens. As they reached these ages, their parents would begin looking for suitable partners for their children by consulting with their friends and relatives. Once the parents found a satisfactory partner, they would consider the partner's family background and social status. This process helped them understand each other and how marriage would be an advantage for each other. In short, in many cases, especially among the upper class, marriage was a kind of business transaction.

Moreover, there were limitations for intermarriages, too. As Twelve Table (Lex XII Tabularum) suggested, the Ancient Rome government enacted clear marriage legislation. The law stated that: "... There shall not be intermarriage between plebeians and patricians...." [9] Since Ancient Rome had a rigid class system, there should not be intermarriages between the rich and the poor. This law would further elaborate on why marriage was regarded as an agreement between two families. People saw marriage as a political tool since creating such a mutual relationship would benefit both economic and military power families. Thus, intermarriage between plebeians and patricians was usually not acceptable.

On top of that, there existed an inequality between men and women in marriages. Titus Maccius Plautus, a well-known playwright, mentions in his play Mercator that men were free to do anything they wanted, even like betraying their wives. In contrast, women were less privileged because society was less tolerant of women's adulterous relationships. He claims:

I' faith, the women do live upon hard terms, and, wretched creatures, on much more unjust ones than the men. For if a husband has been keeping a mistress without the knowledge of his wife, if the wife comes to know it, the husband gets off with impunity; if, unknown to the husband, the wife goes from the house out of doors, a pretext arises for the husband, the marriage is dissolved. I wish the law was the same for the husband as for the wife; for the wife that is a good one is content with one husband; why should the husband be content with one wife? By my troth, I believe that if men were penalized in the same way that women are punished when they make a mistake, there would be more divorced men than women. [10]

Wives' primary responsibilities were childbearing and household maintenance. They also had to be patient with their husbands because men were the ones who created the laws. Aulus Gellius, a famous scholar and author, claims that: "If you catch your wife in adultery, you can kill her with impunity; she, however, cannot dare to lay a finger on you if you commit adultery, nor is it the law." [11] Roman men claimed that men could kill their wives if they found any marital infidelity caused by their wives. Still, women could not revolt or threaten their husbands if they were not loyal to their relationships. Under this unfair circumstance, women were sexually or mentally neglected, but they could not help or change it.

\section{CAESAR'S MOTHER -- AURELIA COTTA}

Caesar's mother, Aurelia, was born in $120 \mathrm{BC}$; her father was the Consul of 119 BC, Lucius Aurelius Cotta. Her husband died when she was in her thirties, so she took on most of the responsibilities as a single mother. In addition to Caesar, she had two daughters named Julia, one of whom was Augustus's maternal grandmother. Aurelia was recognized throughout Rome for her knowledge and virtue, as well as for the wonderful job she did rearing Caesar, not just during those early years, but also in subsequent interactions during his adolescence, young manhood, and eventually throughout Caesar's entire life. [12] In addition, Plutarch considered her as a virtuous and extraordinary woman based on her contributions. [13]

Indeed, Aurelia played a significant role throughout Caesar's life. According to the historian Cornelius Tacitus, he first criticized the deterioration of parenting and then praised Aurelia as an excellent mother and matron by complimenting her abilities in education as well as how that impacted one of the most significant dictators in human history. Based on Tacitus' criticism, many parents failed to raise their children properly. By stating the following ideas in A Dialogue on Oratory, Tacitus emphasized the importance of mothers:

Every citizen's son, the child of a chaste mother, was from the beginning reared, not in the chamber of a purchased nurse, but in that mother's bosom and embrace, and it was her unique glory to study her home and devote herself to her children. It was usual to select an elderly kinswoman of approved and esteemed character to have the entire charge of all the children of the household. It was the last offence to utter an unseemly word or to do a disgraceful act in her presence. With scrupulous piety and modesty, she regulated not only the boy's studies and occupations but even his recreations and games. [14]

Tacitus emphasized that a mother's virtue was essential in raising children because their behaviors 
would directly affect and change their children. In this case, Aurelia was an undoubtedly outstanding mother and educator. Therefore, he concludes that: "Thus it was, as tradition says, that the mothers of the Gracchi, of Caesar, of Augustus, Cornelia, Aurelia, Atia, directed their children's education and reared the greatest of sons. The strictness of the discipline tended to form in each case a pure and virtuous nature which no vices could warp, and which would at once with the whole heart seize on every noble lesson." [14] By complementing Aurelia, Tacitus concluded that Caesar's achievements were closely related to his mother's cultivation because when Caesar was little, Caesar senior was often away. Hence, his mother Aurelia took over the task of raising him. Furthermore, Aurelia raised him with pride in his ancestry because family meant everything to a patrician clan.

One marked characteristic of Caesar's style in his maturity was his elegantia, which is characterized by a delicacy and precision in the use of words. [15] Due to this evidence, it is notable that Caesar gained a lifelong influence from home. The author of The Women of Caesar's Family, Monroe E. Deutsch, definitely states that Aurelia's teaching aided Julius Caesar's distinguishing characteristics and future success. Moreover, Since Aurelia also came from a powerful clan and Caesar's maternal grandfather also served as Consul in 119, his grandfather's consistent support constituted a strong foundation for Caesar's political career at the beginning of Caesar's career.

\section{CAESAR'S FIRST WIFE -- CORNELIA CINNA MINOR}

Cornelia (c. 100-68 BCE) was the daughter of Lucius Cornelius Cinna, and she became the first wife of Julius Caesar in the year 84. Although there was little evidence or documents about the relationship between Cornelia and Caesar existing nowadays, Cornelia remained a crucial role throughout Caesar's early political career because she was a bridge that connected her husband's fortunes with her father's political faction.

Caesar was Cornelia's perfect match because, firstly, like Cornelia, Caesar was a patrician; secondly, his family was closely associated with the Populares faction. Also, through his aunt, he was related to Marius Gaius, the great general. In this case, from the very beginning, Caesar, as Marius' in-law, was regarded as a supporter of Marius. In addition, Cinna had nominated Caesar for the high priest of Jupiter. After marrying Cinna's daughter Cornelia, Caesar showed an unambiguous political stand that he would be the heir to both Marius and Cinna, which meant that he would have much of the support of the populares of the Senate. Therefore, he constituted a great pollical foundation through her wife and father-in-law's power. In fact, his position as high priest of Jupiter gave Caesar particular popularity among the plebeians. The marriage of Caesar to Cornelia also rehabilitated the political fortune of Caesar's branch of his family. In the long term, Caesar demonstrated his ambitions in politics. Therefore, when Lucius Cornelius Sulla demanded him to divorce his wife, he refused. Like professor Lily Ross Taylor brought up in her book Greece \& Rome, she said: "Caesar firmly refused to divorce Cinna's daughter to make a proper marriage, such as Sulla was arranging for other nobles." [16] One explanation stated that Caesar was an ambitious man, and he would not comprise like an incompetent coward. Therefore, to remain popular among the populares and plebeians, he decided to refuse Sulla and maintain his bravery and loyalty to his wife.

Although Caesar and Cornelia's marriage seemed purely political, there was no known animosity or conflicts towards each other. They even had a daughter, Caesar's only legitimate child, Julia. Unfortunately, Cornelia died at a young age. As quaestor, Caesar pronounced the customary orations from the rostra in praise of his wife, Cornelia. [17] It was very unusual to make an oration for such a young woman at that time, but Caesar challenged this norm and impressed people with his sincere eulogy. Therefore, it was logical to speculate that Caesar considered Cornelia as a notable figure in his mind; The story of Cornelia maintained her virtues for centuries after her demise.

\section{CAESAR'S DAUGHTER -- JULIA}

Julia, born in 82, was Caesar's only legitimate child; she was the offspring of Caesar and Cornelia. [15] Since her mother died when she was a teenager, Julia was raised by her grandmother Aurelia. She had been engaged to Marcus Brutus, but in $59 \mathrm{BC}$, Caesar broke off their engagement and married her to Pompey at the time of the formation of the First Triumvirate.

Julia and Pompey's marriage was undoubtedly a political one because there was a significant discrepancy in age between them; Julia was about twenty-four while Pompey was forty-six when they got married. Nevertheless, their marriage seemed like a happy one. Despite the accuracy of the biography, historians like Plutarch provide possibilities that Pompey and Julia's marriage was quite romantic. For instance, Pompey "spent his time with his wife among the pleasure-places of Italy, going from one to another, either because he loved her, or because she loved him so that he could not bear to leave her." [18] Some people even declared that Pompey was very fond of his young wife, who was beautiful and virtuous, and he became a devoted husband. Meanwhile, Julia respected Pompey too, so it was reasonable that they had a good relationship. Also, through this marriage, Julia successfully helped her father and her husband avoid many military conflicts.

However, great misfortunes befell Julia. In 55, Pompey was attacked by thugs during an election, and in 
the fight, his garment was spattered with blood. When Julia saw that, she thought Pompey was dying and was shocked to miscarry. As Plutarch vividly describes as following:

It once happened that at an election of aediles people came to blows, and many were killed in the vicinity of Pompey, and he was covered with their blood, so that he changed his garments. His servants carried these garments to his house with much confusion and haste, and his young wife, who chanced to be with child, at sight of the blood-stained toga, fainted away and with difficulty regained her senses, and in consequence of the shock and her sufferings, miscarried. [18]

Even though Julia conceived again very soon, she died in childbirth, and her baby did not survive either. The political consequence of Julia's death was obvious -the strongest tie that bound Pompey and Caesar was broken, which brought them into further military conflicts and Civil Wars. [15] When Caesar received the news of his daughter's death, he was extremely sorrowful. Pompey and the Romans argued over where to bury Julia. Despite Pompey's plans to bury Julia's dead body at his Alban estate, the people revolted and forcibly carried Julia's body down to the Campus Martius for burial. The argument was not a conflict between Caesar and Pompey, but it was clear that Julia had a flawless reputation, which further elaborated her achievements. [18]

Nevertheless, Julia was indisputably a model for Ancient Roman women. She is a great politician dealing with clashes between her father and her husband when she was alive. It was evident that she succeeded in becoming a bridge between the two most powerful leaders. Hence, Julia had always been a perfect image to stay in the hearts of the Romans.

\section{CONCLUSION}

In conclusion, this paper analyzes factors that led to the women's involvement in Ancient Roman politics: outcome of political marriages and significant roles in families. Utilizing three specific exemplifications: Aurelia, Cornelia, and Julia, this paper examines the stories of three aristocratic women and how they influenced politics during the reign of Julius Caesar. Given the importance of those women's roles, it is vital and powerful to acknowledge their contributions to families and society. Using Julius Caesar's example, women were undeniably a critical part of a family. They helped connect different families and allies, took care of the household, and assisted Julius Caesar to make correct decisions. However, due to a scarcity of archival papers and historical data, telling the history of different women in Ancient Rome, such as plebeians and women in the Ancient Rome Empire, is not always possible. Most of the evidence only revealed aristocratic women who held a high reputation and status in society. Therefore, it is significant to dig into the realm of gender studies and so incorporate a very diverse source to understand Ancient Roman women from all classes.

\section{REFERENCES}

[1] Citatis. n.d. Cato the Elder Quotes. https://citatis.com/a31739/.

[2] Internet History Sourcebooks. n.d. Fordham.Edu. https://sourcebooks.fordham.edu/ancient/livyrape.asp.

[3] Lapine, S. (2019) Director's Note: Who Was Lucretia and Why Does Her Story Still Matter to Us?. https://blog.blo.org/directors-note-who-waslucretia-and-why-does-her-story-still-matter-to-us.

[4] Matthes, M. 2001. The Rape of Lucretia and the Founding of Republics: Readings in Livy, Machiavelli, and Rousseau. Pennsylvania State University Press, University Park, FL.

[5] Blogspot. (2012) The Rape of Lucretia and the Establishment of the Republic. http://dustinsimmons.blogspot.com/2012/01/rapeof-lucretia-and-establishment-of.html.

[6] Holland, T. (2004) Rubicon: The Last Years of the Roman Republic. Doubleday Books.

[7] Mitchell, T. (1973) CICERO, POMPEY, AND THE RISE OF THE FIRST TRIUMVIRATE. Tradition 29: $1-26$.

[8] Gregory S Aldrete. (2018) The Role of Women in Ancient Rome-Piecing Together A Historical Picture.

https://www.thegreatcoursesdaily.com/role-ofwomen-in-ancient-rome/.

[9] Johnson A., Coleman-Norton P. \& Bourne F. Lex XII Tabularum ( English Translation: ARS ). n.d. Univ-Grenoble-Alpes.Fr. https://droitromain.univgrenoble-alpes.fr/Anglica/twelve_Johnson.html.

[10] T. Maccius Plautus, Mercator, or The Merchant, Act 4, Scene 5. n.d. Tufts.Edu. http://www.perseus.tufts.edu/hopper/text?doc=Pers eus\%3Atext\%3A1999.02.0102\%3Aact\%3D4\%3As cene $\% 3 \mathrm{D} 5$.

[11] Ceaicovschi, K. (2009) Cato the Elder in Aulus Gellius. Illinois Classical Studies, no. 33-34: 25-39.

[12] Billows, R. (2011) Julius Caesar: The Colossus of Rome. Routledge, London, England.

[13] Plutarch. (2010) Plutarch: Lives of the Noble Grecians and Romans. MVB E-Books.

[14] Cornelius Tacitus, A Dialogue on Oratory, Chapter 28. n.d. Tufts.Edu. 
http://www.perseus.tufts.edu/hopper/text?doc=Pers eus\%3Atext\%3A1999.02.0082\%3Achapter\%3D28 .??

[15] Deutsch, M. (1918) The Women of Caesar's Family. The Classical Journal 13, no. 7: 502-14.

[16] Taylor, Lily Ross. (1957) The Rise of Julius Caesar. Greece \& Rome 4, no. 1: 10-18.

[17] Suetonius. (1913) The Life of Julius Caesar. Uchicago.Edu. Loeb Classical Library. https://penelope.uchicago.edu/Thayer/E/Roman/Te xts/Suetonius/12Caesars/Julius*.html\#6.

[18] "Plutarch, Pompey, Chapter 53." n.d. Tufts.Edu. Accessed August 3, 2021. 